\title{
18. ORGANIC GEOCHEMISTRY, LEG 38: INTRODUCTION TO STUDIES
}

\author{
Keith A. Kvenvolden, U.S. Geological Survey, Menlo Park, California
}

Samples from cores obtained on Leg 38 in the Norwegian-Greenland Sea provide sedimentary materials from a very young ocean of small size with a diversity of geological structures. The sedimentary record gives organic geochemists the opportunity to study early diagenesis in various structural contexts and to investigate source materials in the Arctic environment.

For organic geochemical studies $10520-\mathrm{cm}$ whole core segments (Table 1) were collected for the JOIDES Organic Geochemistry Panel from 14 of the 17 sites drilled on Leg 38. These segments were frozen immediately, and were kept frozen. Segments of the cores remaining after the initial sampling are maintained frozen at the DSDP facilities, Scripps Oceanographic Institution. These samples are available for more detailed investigations.

Five investigators from the Organic Panel selected parts of various core segments for detailed study and present their reports in the papers that follow. Another paper, following this section, deals with organic diagenesis of Miocene sediments from Site 341. This paper was written by D.A. Morris, who was the shipboard organic geochemist. His study was based on samples specifically chosen by him and are not part of the sample group taken by him for the Organic Geochemistry Panel.

The samples range in age from early Eocene to Pleistocene. Organic carbon content is generally less than $2 \%$, with most of the sediments containing less than $1 \%$ organic carbon. The Pliocene and Pleistocene section is made up mostly of glacially derived sediments. Older sediments are composed of diatomaceous ooze, pelagic mud and clay, and sandy mudstone.

During the drilling at Site 341 on the landward side of the V $\phi$ ring Plateau Escarpment, observations were made of particular interest to organic geochemists. Talwani et al. (1975) reported that "...small pockets of gas formed in virtually every core recovered below a depth of 50 meters. All but one sample contained methane, and nearly all gas samples from the Miocene contained traces of ethane. Methane content increases rapidly below 183 meters in the Pleistocene and decreases below 343 meters in the Miocene. Miocene sediments near the base of the hole have a strong petroliferous odor and produce a bright yellow fluorescence." Coring was terminated at 456 meters for safety reasons, and the hole was cemented.

Shore-based organic geochemical studies of the Miocene sediments at Site 341 failed to indicate the presence of anomalously high concentrations of lipids or hydrocarbon substances. Erdman's data (this volume) shows that the percentage of lipids, relative to the organic carbon, ranges from 1.1 to 2.2. These values are in the same general range as found in other samples in this core and in other cores. Hood (this volume) determined the percentage hydrocarbons generated during laboratory pyrolysis of part of the same samples. Values obtained of $0.26 \%$ or less are considered low and are not indicative of the presence of significant concentrations of hydrocarbons.

Interpretations vary with regard to the potential of the sediments for petroleum genesis. Erdman suggests that at Sites 338, 341, 346, 348, and 349 the overall properties of the sedimentary sections appear favorable for the genesis of significant quantities of petroleum; however, petroleum genesis is in a very early stage. At Site 339 , early or middle Oligocene sediments, he believes, have properties that are comparable to those associated with many petroleum accumulations. The higher thermal history at this site may account for the advanced stage of petroleum genesis. Anomalously high lipid values for a Pliocene or Pleistocene sample at Site 341 and a Pliocene (?) sample at Site 344 are believed to be the consequence of an age and thermal history different from the core itself. At Site 345 in a single sample from a similar age interval, Simoneit (this volume) finds droplets of hydrocarbons having alkane distributions typical of petroleum. He believes that the oil migrated from an unidentified source lower in the sedimentary section. In contrast to Erdman's interpretations, Hood (this volume) argues, on the basis of source-rock measurements applied here for the first time to DSDP samples, that none of the samples analyzed for Sites $338,341,344$, and 346 are potential sources for significant oil accumulations. Using measurements of $\mathrm{C}_{4}-\mathrm{C}_{7}$ hydrocarbons from samples at Sites $336,338,345$, and 348 , Hunt (this volume) concurs that none of these samples has sufficient hydrocarbon potential to be of significance in indicating a possible petroleum province.

In addition to studies directed toward evaluating the extent of hydrocarbon diagenesis and the potential of sediments for petroleum genesis, Baker (this volume) has attempted to follow the diagenesis of pigments. He found abundant chlorins in the Miocene sediments, although chlorins are generally characteristic of younger sediments. In a Pleistocene sample from Site 341 and a Pliocene or Pleistocene sample from Site 344, vanadyl porphyrins were found together with chlorins. Vanadyl porphyrins are considered to be the products of advanced diagenesis not usually occurring in Pleistocene sediments. Therefore, the association of chlorins and vanadyl porphyrins is thought to indicate that the sediments are a mixture of very old and very young materials. Perhaps the same factors that account for the unusual occurrence of vanadyl porphyrins also apply to the anomalous lipid concentrations in sediments of similar age from the same cores as described by Erdman.

\section{REFERENCE}

Talwani, M., Udintsev, G., Bjørklund, K., Caston, V.N.D., Faas, R.W., Kharin, G.N., Morris, D.A., Muller, C., Nilsen, T.H., van Hinte, J.E., Warnke, D.A., and White, S.M., 1975. Leg 38-Deep Sea Drilling Project: Geotimes, v. 20 , p. $24-26$. 
K. A. KVENVOLDEN

TABLE 1

Inventory of 20-cm Frozen Core Segments, Leg 38 (Numbers Indicate Core-Section)

\begin{tabular}{|c|c|c|c|c|c|c|c|c|c|c|c|c|c|}
\hline \multicolumn{14}{|c|}{ Site } \\
\hline 336 & 337 & 338 & 339 & 341 & 342 & 343 & 344 & 345 & 346 & 348 & 349 & 350 & 352 \\
\hline $2-3$ & $1-5$ & $1-4$ & $4-2$ & $2-1$ & $1-5$ & $1-3$ & $5-5$ & $1-2$ & $1-3$ & $1-0$ & $5-5$ & $2-4$ & $1-3$ \\
\hline $5-3$ & & $3-1$ & $6-2$ & $4-1$ & $2-2$ & $3-5$ & $7-5$ & $4-1$ & $4-3$ & $1-5$ & $9-3$ & $4-3$ & $4-0$ \\
\hline $8-3$ & & $5-5$ & $8-4$ & $6-2$ & $3-2$ & $4-3$ & $9-5$ & $8-3$ & $7-3$ & $3-5$ & & $8-3$ & \\
\hline $11-2$ & & $8-2$ & $12-1$ & $8-3$ & $4-1$ & $5-5$ & $11-1$ & $10-5$ & $10-4$ & $5-1$ & & $10-3$ & \\
\hline $12-1$ & & $11-2$ & & $10-5$ & $6-1$ & $7-3$ & $15-4$ & $14-4$ & $12-4$ & $7-4$ & & & \\
\hline $16-5$ & & $13-5$ & & $20-3$ & & $9-1$ & $27-3$ & $16-4$ & $15-4$ & $9-4$ & & & \\
\hline $18-3$ & & $17-5$ & & $23-4$ & & $11-2$ & $31-2$ & $17-3$ & $17-2$ & $11-4$ & & & \\
\hline $20-4$ & & $19-4$ & & $25-5$ & & & & $19-5$ & & $13-1$ & & & \\
\hline $22-4$ & & $22-5$ & & $28-5$ & & & & $21-5$ & & $15-1$ & & & \\
\hline $23-4$ & & $24-5$ & & $30-5$ & & & & $23-4$ & & $19-5$ & & & \\
\hline $25-5$ & & $26-2$ & & $32-5$ & & & & $26-4$ & & $21-5$ & & & \\
\hline $27-4$ & & $30-5$ & & $34-5$ & & & & $29-1$ & & $23-5$ & & & \\
\hline $30-3$ & & $32-3$ & & & & & & & & $29-0$ & & & \\
\hline $33-4$ & & & & & & & & & & & & & \\
\hline $35-4$ & & & & & & & & & & & & & \\
\hline $39-4$ & & & & & & & & & & & & & \\
\hline
\end{tabular}

